\title{
Article \\ Influence of the Solution and Artificial Aging Treatments on the Microstructure and Mechanical Properties of Die-Cast Al-Si-Mg Alloys
}

\author{
Ho-Jung Kang ${ }^{1,2} \mathbb{D}$, Jin-Young Park ${ }^{1}$, Yoon-Suk Choi ${ }^{2, *}$ and Dae-Hyun Cho ${ }^{3, *}$
}

Citation: Kang, H.-J.; Park, J.-Y.; Choi, Y.-S.; Cho, D.-H. Influence of the Solution and Artificial Aging Treatments on the Microstructure and Mechanical Properties of Die-Cast Al-Si-Mg Alloys. Metals 2022, 12, 71. https://doi.org/10.3390/met12010071

Academic Editor:

Francesco Iacoviello

Received: 15 December 2021

Accepted: 28 December 2021

Published: 31 December 2021

Publisher's Note: MDPI stays neutral with regard to jurisdictional claims in published maps and institutional affiliations.

Copyright: (C) 2021 by the authors. Licensee MDPI, Basel, Switzerland. This article is an open access article distributed under the terms and conditions of the Creative Commons Attribution (CC BY) license (https:// creativecommons.org/licenses/by/ $4.0 /)$.
1 Advanced Forming Process R\&D Group, Korea Institute of Industrial Technology, Ulsan 44776, Korea; hjkang7@kitech.re.kr (H.-J.K.); jpark7@kitech.re.kr (J.-Y.P.)

2 Department of Materials Science and Engineering, Pusan National University, Busan 46287, Korea

3 Department of Materials Science and Engineering, The Ohio State University, Columbus, OH 43210, USA

* Correspondence: choiys@pusan.ac.kr (Y.-S.C.); cho.1151@osu.edu (D.-H.C.); Tel.: +82-10-2070-6186 (Y.-S.C. \& D.-H.C.)

\begin{abstract}
Heat treatment is widely used to improve the properties of $\mathrm{Al}-\mathrm{Si}-\mathrm{Mg}$ alloys and its outcomes are influenced by the parameters applied during the treatment. This study describes the effect of the solution and artificial aging treatments on the microstructure and mechanical properties of die-cast $\mathrm{Al}-\mathrm{Si}-\mathrm{Mg}$ alloys. The microstructure of the as-cast $\mathrm{Al}-\mathrm{Si}-\mathrm{Mg}$ alloy was mainly composed of $\alpha$-Al, complex needle-type eutectic Si particles, $\mathrm{Mg}_{2} \mathrm{Si}$, and $\alpha$-AlFeMn. The complex needle-type eutectic Si particles disintegrated into spheroidal morphologies, while the $\mathrm{Mg}_{2} \mathrm{Si}$ was dissolved due to the solid solution treatment. The maximum yield strength (YS) and ultimate tensile strength (UTS) values were 126.06 and $245.90 \mathrm{MPa}$ at $520^{\circ} \mathrm{C}$ after $90 \mathrm{~min}$ of solution heat treatment, respectively. Although the YS and UTS values of the Al-Si-Mg alloys reduced due to the solution treatment, the elongation (EL) of the solid solution heat-treated Al-Si-Mg alloys was improved in comparison to that of the as-cast Al-Si-Mg alloy. The maximum YS and UTS of 239.50 and $290.93 \mathrm{MPa}$ were obtained after performing artificial aging at $180{ }^{\circ} \mathrm{C}$ for $180 \mathrm{~min}$, respectively. However, the EL of the aging heat-treated alloy was reduced by a minimal value.
\end{abstract}

Keywords: Al-Si-Mg alloy; high-pressure die casting; solution treatment; artificial aging treatment; mechanical properties; microstructural change

\section{Introduction}

Die-cast Al-Si-Mg alloys have been widely used in compact applications, such as automobiles, motorcycles and sizeable marine applications owing to their excellent weldability, high strength-to-density ratio, and resistance against corrosion. The alloys used in these complex structural components must have excellent fluidity and castability. They should have an optimized chemical composition and be subjected to heat treatments to enhance their mechanical properties and corrosion resistance [1-3].

$\mathrm{Si}$ is known to have good castability and excellent die-filling properties. $\mathrm{Mg}$ increases the yield strength of an alloy at the expense of its ductility [3-6]. The microstructures of these as-cast alloys consisted of $\alpha$-Al, eutectic Si particles, and $\mathrm{Mg}_{2} \mathrm{Si}$ phases. Moreover, they can contain particles of several intermetallic compounds, such as $\mathrm{Mn}, \mathrm{Fe}$, and $\mathrm{Cu}$. The formation of coarse and brittle eutectic Si and $\mathrm{Mg}_{2} \mathrm{Si}$ phases with complex acicular shapes during solidification damages the mechanical properties of the alloys because it leads to localised stress concentration in the matrix. Thus, the commercial die casting of $\mathrm{Al}-\mathrm{Si}-\mathrm{Mg}$ alloys essentially involves the addition of alloying elements, such as $\mathrm{Sr}$ and $\mathrm{Na}$, and includes heat treatments.

The addition of $\mathrm{Si}$ in commercial Al-Si-Mg alloys, such as Silafont ${ }^{\mathrm{TM}}$, Castasil ${ }^{\mathrm{TM}}$, Aural $^{\mathrm{TM}}$, and Mercalloy ${ }^{\mathrm{TM}}$, induced a hypoeutectic or near-eutectic composition that ranges 
from 6.0 to $12 \mathrm{wt} . \%$. Moreover, it is essential to ensure that the concentration of $\mathrm{Mg}$ does not exceed $0.7 \mathrm{wt} . \%$ because it is likely to significantly damage the mechanical properties of the alloy through the formation of brittle intermetallic phases that contain trace elements, such as $\mathrm{Fe}, \mathrm{Ni}$, and $\mathrm{Cu}[7-9]$. Furthermore, the addition of $\mathrm{Sr}(0.01-0.02$ wt.\%) modifies the eutectic $\mathrm{Si}$, thereby improving the ductility of the alloy. It also plays a crucial role in increasing the resistance of the alloy to die soldering, especially at high concentrations $(0.05-0.07 \mathrm{wt} . \%)$ [10]. High concentrations of Sr increase the porosity in thick sections and processes by slowing down the solidification rate; however, this is not applicable in die casting, which requires the application of intense pressures. The porosity is dispersed from a macroscale to a microscale. The increasing percentage of $\mathrm{Mg}$ in $\mathrm{Al}-\mathrm{Si}$ alloys increases the percentage of $\mathrm{Mn}$ required to overcome die soldering. Mn reduces die soldering and corrects the Fe phase by transforming the $\beta$-Fe needles $\left(\mathrm{FeSiAl}_{5}\right)$ into the Chinese script-like morphology $\left(\alpha-\mathrm{Fe},\left(\mathrm{Fe}, \mathrm{Mn}_{3} \mathrm{Si}_{2} \mathrm{Al}_{15}\right)\right.$. Additionally, Mn provides good ejection behaviour [11-15].

Several studies have investigated different heat treatment parameters, such as the solution temperature, aging temperature, and cooling speed. The T6 heat treatment process is commonly used for die-casting $\mathrm{Al}$ alloys and is described below [16-18].

1. Solution treatment involves heat treatment at a temperature similar to the eutectic point temperature or a relatively high temperature to dissolve soluble phases formed during solidification. This ensures that a homogeneous concentration of the alloying elements is obtained in the solid solution. These elements then form a spheroid around the eutectic Si particles.

2. Solution treatment is followed by quenching, which is used to suppress the occurrence of precipitation while cooling the cast to room temperature. A high quench rate ensures that the solute is retained in the solid solution, in addition to several vacancies. However, if the cooling process is too slow, particles precipitate heterogeneously at grain boundaries or dislocations. This reduces the supersaturation of the solute, thereby lowering the maximum yield strength of the alloy after aging. However, rapid cooling of the alloy induces thermal stresses in the cast.

3. Hardening due to aging results in precipitation from a supersaturated solid solution. Aging occurs at room temperature (natural aging) or at an elevated temperature between 150 and $210{ }^{\circ} \mathrm{C}$ (artificial aging). Aging is performed to produce a uniform distribution of small precipitates that increase the strength of the alloy.

Recent studies on the heat treatments of Al-Si-Mg alloys analyzed the effects of the modification of brittle intermetallic phases and hardening caused by aging, through an investigation of the parameters involved in each heat treatment step $[1,2,19,20]$. The T6 heat treatment of the commercial Al-Si-Mg alloy Silafont ${ }^{\mathrm{TM}} 36$ involves solid solution heat treatment at $480-490{ }^{\circ} \mathrm{C}$ for $2-3 \mathrm{~h}$. A cooling rate of $10-60{ }^{\circ} \mathrm{C}$ is maintained, followed by aging at $155-170{ }^{\circ} \mathrm{C}$ for $2-3 \mathrm{~h}$. Studies have been conducted to explore the effect of the aging process during heat treatment on the microstructure and mechanical properties of the Al-Si-Mg alloys. Pfarelo et al. [21] subjected an Al-0.36Mg-7.14Si alloy to heat treatment at $540^{\circ} \mathrm{C}$ for $1 \mathrm{~h}$, followed immediately by water quenching. The alloy was then aged at $190{ }^{\circ} \mathrm{C}$ for several durations varying from $0-128 \mathrm{~h}$. The alloy subjected to aging for $2 \mathrm{~h}$ at $190^{\circ} \mathrm{C}$ was reported to have the maximum peak hardness, owing to the aging of the Si-rich phases. Mohamed et al. [22] studied the effect of aging at 160 and $220{ }^{\circ} \mathrm{C}$ for a maximum duration of $200 \mathrm{~h}$ on an $\mathrm{Al}-\mathrm{Si}-\mathrm{Mg}$ alloy. The alloy was heat-treated in a solid solution at $540{ }^{\circ} \mathrm{C}$ for $12 \mathrm{~h}$, followed by water quenching. The solutionization of the $\mathrm{Al}-\mathrm{Si}-\mathrm{Mg}$ alloy resulted in the simultaneous coarsening of the eutectic Si particles and the modification of the intermetallic compounds containing Fe. They also observed that the $\mathrm{Mg}_{2} \mathrm{Si}$ phases, which were initially in the form of thin platelets, developed a spherical morphology during artificial aging. Li et al. [23] discovered the presence of the hardness and single peaks in the aging-hardening curve of the Al-10Si-0.4Mg alloy at $175^{\circ} \mathrm{C}$. This was attributed to the continuous transformation of the alloy from the Guinier-Preston zone to the transition phase. Sharma et al. [24] studied the effects of silicon addition and 
precipitation hardening treatment on a cast $\mathrm{Al}-(4-20 \%) \mathrm{Si}-0.3 \mathrm{Mg}$ alloy. The alloy was subjected to solution treatment at $510^{\circ} \mathrm{C}$ for $4 \mathrm{~h}$, followed by water quenching and aging at 170 and $210{ }^{\circ} \mathrm{C}$ for $12 \mathrm{~h}$. The microstructure was composed of $\alpha$-Al and a eutectic mixture of $\mathrm{Al}-\mathrm{Si}$ in the inter-dendritic region until the Si concentration increased to $12 \mathrm{wt} . \%$ due to $\mathrm{Si}$ addition. The dendritic structure broke down after precipitation hardening and spheroidised the eutectic Si particles. Furthermore, there are studies that have attempted to analyze the precipitation behaviours of $\mathrm{Al}-\mathrm{Si}-\mathrm{Mg}$ alloys during solution treatment. Lin et al. [25] discussed the effect of the solution treatment at $540{ }^{\circ} \mathrm{C}$ on a Sr-modified $\mathrm{Al}-\mathrm{Si}-\mathrm{Mg}$ alloy. It was observed that the microstructural evolution and the mechanism of eutectic Si particles during solution time and the dispersion strengthening effect related to the solid solution. Zhang et al. [26] investigated the impact of the solute percentages of the $\mathrm{Al}-\mathrm{Si}-\mathrm{Mg}$ alloy at a solution temperature of $525-560^{\circ} \mathrm{C}$ during the $\mathrm{T} 6$ heat treatment process. Long et al. [27] observed that a lengthy solution duration degraded the aging kinetics and aging hardening due to the diffusion of the enrichment $\mathrm{Mg}$ towards the inevitable casting porosity.

Previous studies have analyzed the effect of the solution treatment temperature and time on the gas porosity and mechanical properties of castings. As the solution heat treatment temperature $\left(480-540^{\circ} \mathrm{C}\right)$ and time $(0.5-1.5 \mathrm{~h})$ increased, the mechanical properties increased, but bubble defects also expanded due to heat treatment. Accordingly, the maximum UTS and YS were obtained under the condition of solution treatment at $520{ }^{\circ} \mathrm{C}$ for $1.5 \mathrm{~h}$. This is thought to be a combination effect of the increase in the strength by precipitation strengthening and decrease in the strength due to initial crack sites and the propagation paths of the gas porosity [28].

This study aims to develop an optimal heat treatment technique for die-cast $\mathrm{Al}-\mathrm{Si}-\mathrm{Mg}$ alloys. Minimal amounts of Sr and Mn were added to the Al-11Si-0.5Mg alloy to modify the eutectic Si particles and suppress die soldering. The microstructure and mechanical properties of the alloy were investigated to analyse the effects of solution treatment and artificial aging treatment through optical microscopy (OM), scanning electron microscopy (SEM), X-ray diffraction analysis (XRD), energy-dispersive X-ray spectroscopy (EDS), and tensile tests.

\section{Materials and Methods}

The specimens were produced using a 125-ton cold chamber die casting machine (TOYO, TOYO125, Ulsan, Korea). The machine was equipped with a vacuum system to reduce gas porosity. The casting was designed to produce various analytical test specimens, as shown in Figure 1 [29]. Minimal amounts of $\mathrm{Sr}$ and $\mathrm{Mn}$ were added to the Al-11Si$0.5 \mathrm{Mg}$ alloy to modify the eutectic Si particles and suppress die soldering. The chemical composition of the modified Al-Si-Mg alloy is listed in Table $1[5,6,20]$. The melt was argon-degassed using a rotor impeller at a speed of $300 \mathrm{rpm}$ for $8 \mathrm{~min}$. The casting and die temperatures were maintained at 680 and $200{ }^{\circ} \mathrm{C}$, respectively. The slow shot speed steadily increased from 0.1 to $0.25 \mathrm{~m} / \mathrm{s}$, and the fast shot speed was set to $1.5 \mathrm{~m} / \mathrm{s}$. The plunger moved $100 \mathrm{~mm}$ into the shot sleeve. Thereafter, the vacuum system was activated, and the vacuum pressure was maintained between 140 and 170 mbar. The specimens were subjected to solution and artificial aging treatments, the details for which are shown in Table 2 and Figure 2. The solution treatment was conducted at various temperatures (480, 500,520 , and $540{ }^{\circ} \mathrm{C}$ ), followed by natural aging. The alloy was then cooled with an air spray (fan). The cooling rate was calculated with respect to the time taken by the alloy to attain a temperature of $25^{\circ} \mathrm{C}$ using a DAQ system (Data acquisition system; Donghyun, T.C., Ulsan, Korea), as shown in Table 2. The solution treatment at $520^{\circ} \mathrm{C}$ was followed by artificial aging at 160,170 , and $180{ }^{\circ} \mathrm{C}[1,17,29]$. 


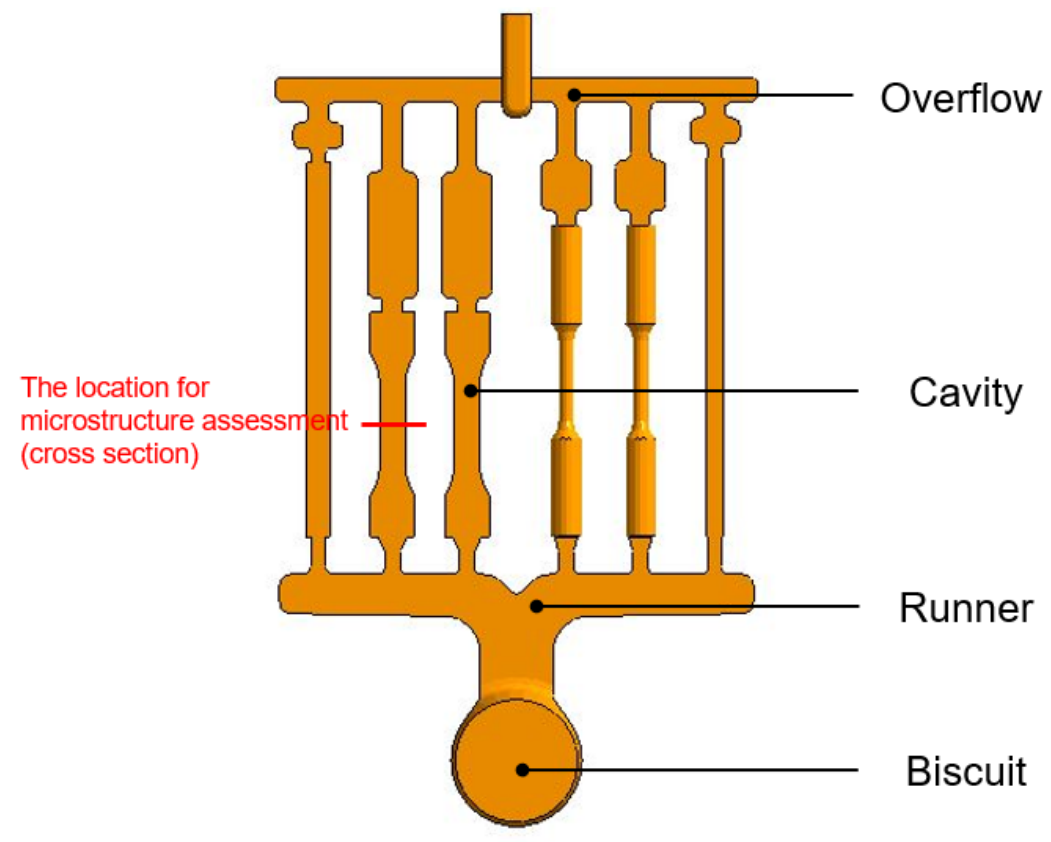

Figure 1. Schematic of the casting with gating and venting.

Table 1. Chemical composition (wt.\%) of the alloy used in this study.

\begin{tabular}{ccccccccccc}
\hline $\mathbf{\%}$ & $\mathbf{S i}$ & $\mathbf{F e}$ & $\mathbf{C u}$ & $\mathbf{M n}$ & $\mathbf{M g}$ & $\mathbf{C r}$ & $\mathbf{Z n}$ & $\mathbf{T i}$ & $\mathbf{S r}$ & $\mathbf{A l}$ \\
\hline Alloy & 11.480 & 0.138 & 0.022 & 0.788 & 0.545 & 0.0025 & 0.0110 & 0.0975 & 0.019 & Bal. \\
\hline
\end{tabular}

Table 2. Parameters of the heat treatment process.

\begin{tabular}{cccccc}
\hline & \multicolumn{3}{c}{ Solution Treatment } & \multicolumn{2}{c}{ Age Treatment } \\
\cline { 2 - 6 } No. & Temp. $\left(\mathbf{T}_{\mathbf{1}},{ }^{\circ} \mathbf{C}\right)$ & Time (Min) & Cooling Method & Temp. $\left(\mathbf{T}_{\mathbf{2}},{ }^{\circ} \mathbf{C}\right)$ & Time (Min) \\
\hline 1 & - & - & - & - & - \\
2 & 480 & & & - & - \\
3 & 500 & & Air cooling (fan) & - & - \\
4 & 520 & & $\left(157.8{ }^{\circ} \mathrm{C} / \mathrm{min}\right)$ & - & - \\
5 & 540 & & & 160 & \\
6 & & & & 170 & 180 \\
7 & 520 & & & 180 & \\
8 & & & & & \\
\hline
\end{tabular}

The specimens used for the microstructure analysis were obtained from the central portion of the tensile test bar and were hot mounted, ground, and polished. Optical microscopy (OM; Hirox, RH-2000, Ulsan, Korea) was used to analyse the secondary dendrite arm spacing (SDAS) and eutectic Si. The porosity of the specimens was assessed according to the density measurements performed by the Archimedes method. The detailed microstructures of the different phases of the specimens were analyzed through field emission scanning electron microscopy (FE-SEM; Hitachi, SU8020, Ulsan, Korea) in conjunction with energy dispersive spectroscopy (EDS). X-ray diffraction (XRD; Bruker AXS, D8 ADVANCE, Ulsan, Korea) was used to analyse the phase components of the specimens. Tensile tests were conducted using a universal testing system (Instron, Instron5989, Ulsan, Korea) according to the ASTM E08 standard. An extensometer with a gauge length of $25 \mathrm{~mm}$ and strain rate of $1 \mathrm{~mm} / \mathrm{min}$ was used. The results were obtained from a minimum of six samples that did not show any notable defects [29]. 


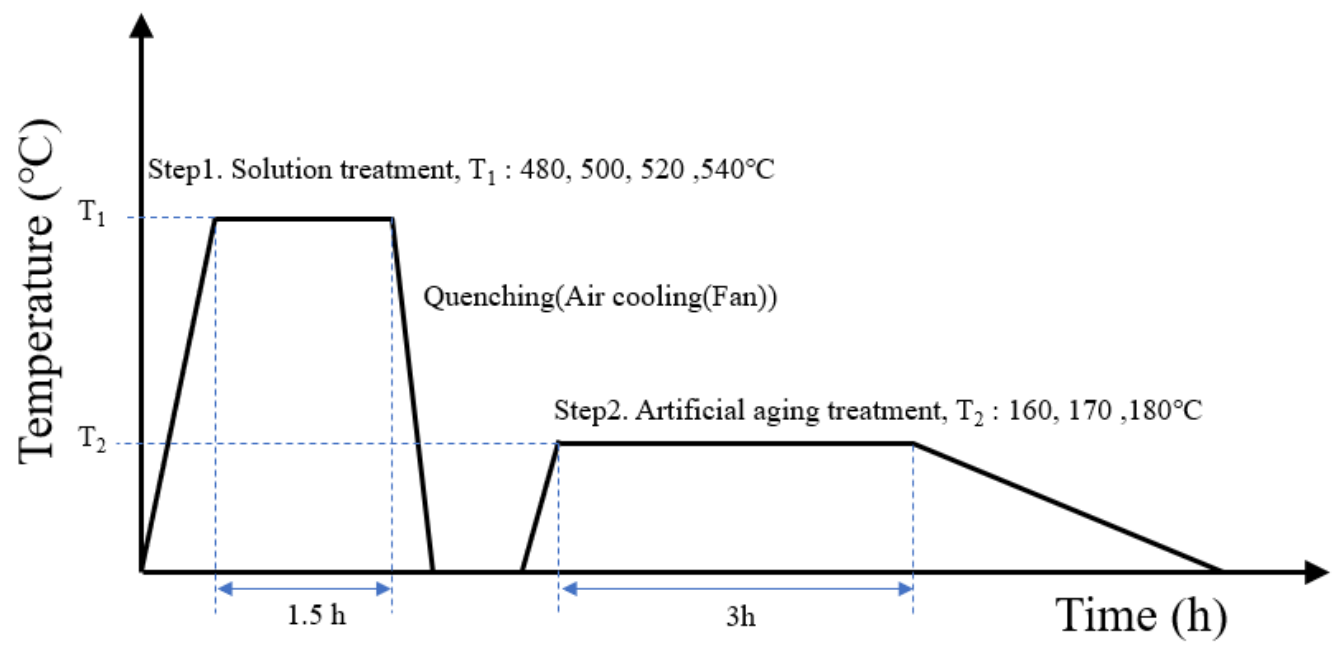

Figure 2. Schematic of the solution treatment and artificial aging treatment.

\section{Results}

Figure 3 shows the dendritic structures of the die-cast and solution heat-treated Al$11 \mathrm{Si}-0.5 \mathrm{Mg}$ alloys. The presence of $\alpha-\mathrm{Al}$ cells are noted in Figure 3a. The coarse eutectic mixtures and intermetallic compounds were located in the inter-dendritic region. Most of the solute elements accumulated at the solid/liquid interface and precipitated during solidification. The die-cast coarse eutectic mixtures and intermetallic compounds were broken into spheroidized morphologies after the solid solution heat treatment, as shown in Figure 3b-e. The XRD analysis indicated that these eutectic mixtures and intermetallic compounds in the inter-dendritic region were composed of eutectic $\mathrm{Si}, \mathrm{Mg}_{2} \mathrm{Si}$, and $\alpha$ AlFeMn intermetallic compounds (Figure 4).
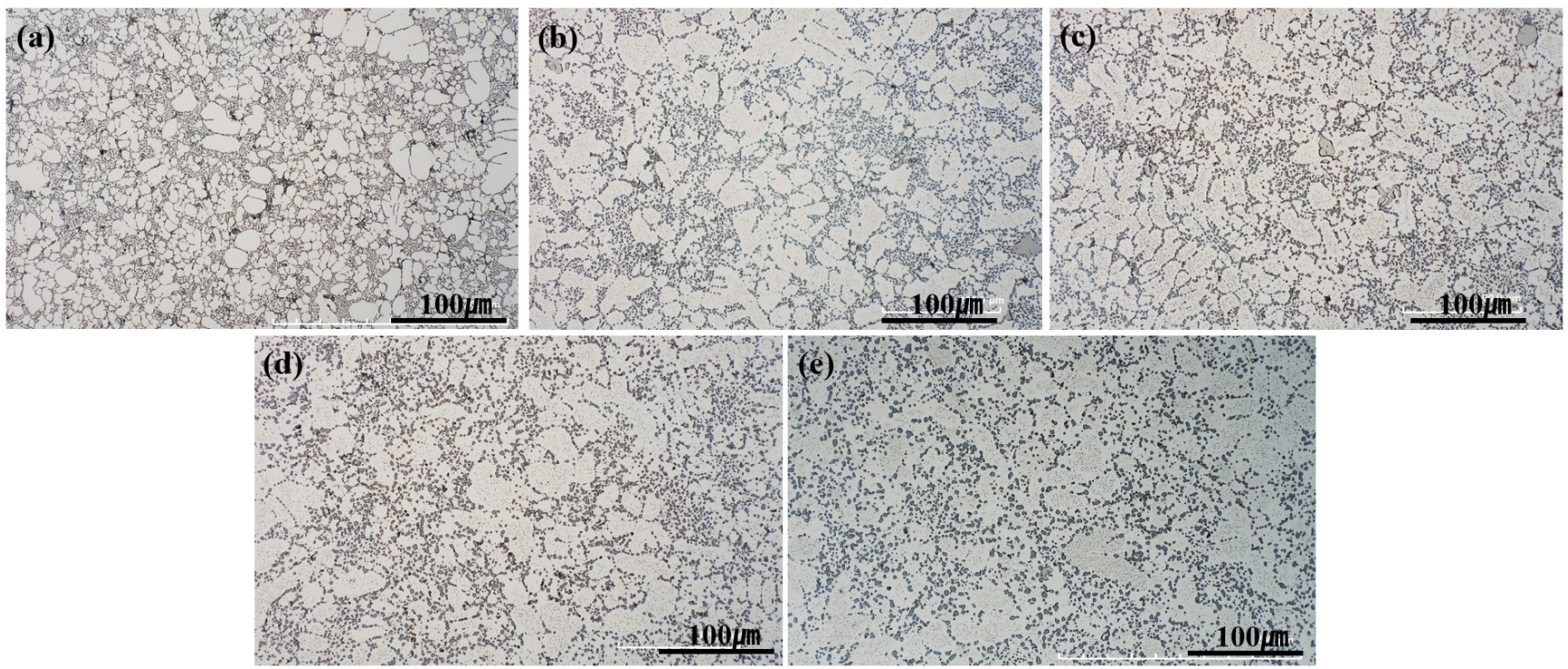

Figure 3. Optical micrographs of the specimens (a) as-cast, and after solution treatments at (b) $480{ }^{\circ} \mathrm{C}$, (c) $500{ }^{\circ} \mathrm{C}$, (d) $520^{\circ} \mathrm{C}$, and (e) $54{ }^{\circ} \mathrm{C}$ for $90 \mathrm{~min}$.

The FE-SEM images of the morphologies and sizes of eutectic $\mathrm{Si}, \mathrm{Mg}_{2} \mathrm{Si}$, and $\alpha$-AlFeMn phases are shown in Figure 5. It can be observed that the eutectic Si and $\mathrm{Mg}_{2} \mathrm{Si}$ phases in the die-cast Al-11Si-0.5Mg alloy had a complicated needle-type morphology, while the $\alpha$-AlFeMn phase had a globular morphology. The complicated needle-type morphology of the eutectic $\mathrm{Si}$ and $\mathrm{Mg}_{2} \mathrm{Si}$ phases transformed into a spheroidal morphology after the solid solution heat treatment (Figure 5b-e). The coarsened Si particle morphologies were 
composed of spherical and polyhedral morphologies, as shown in Figure 5e. The Si crystal

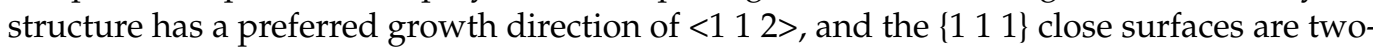
fold for the Si crystal. The atomic binding is strong along the two-fold $\left\{\begin{array}{lll}1 & 1 & 1\end{array}\right\}$ close-packed surfaces. Thus, the growth of Si particles can lead to the formation of facets with sharp edges at high temperatures or after long durations of heat treatment $[20,30]$. The eutectic Si particles were smaller than the transformed Si particles. Several studies have observed that the rapid solidification caused by high-pressure die casting affects the refinement of eutectic Si particles [31]. Chen et al. [16] reported that the thicknesses of the plate-shaped Si particles of die-cast Al-Si alloys varied from 150 to $250 \mathrm{~nm}$. The particles developed a spheroidal morphology with an average diameter of $2.03 \mu \mathrm{m}$. The spheroidization of the eutectic Si particles through the heat treatment process occurs in two stages, namely the fragmentation or dissolution of the eutectic silicon branches and the spheroidization of the separated branches. However, the results showed that the treatments applied in this study were not able to dissolve or break up the eutectic Si particles, which confirmed the assumption that the solid-solution heat treatment leads to the growth and transformation of the morphology of the eutectic Si particles, as shown in Figure 5.

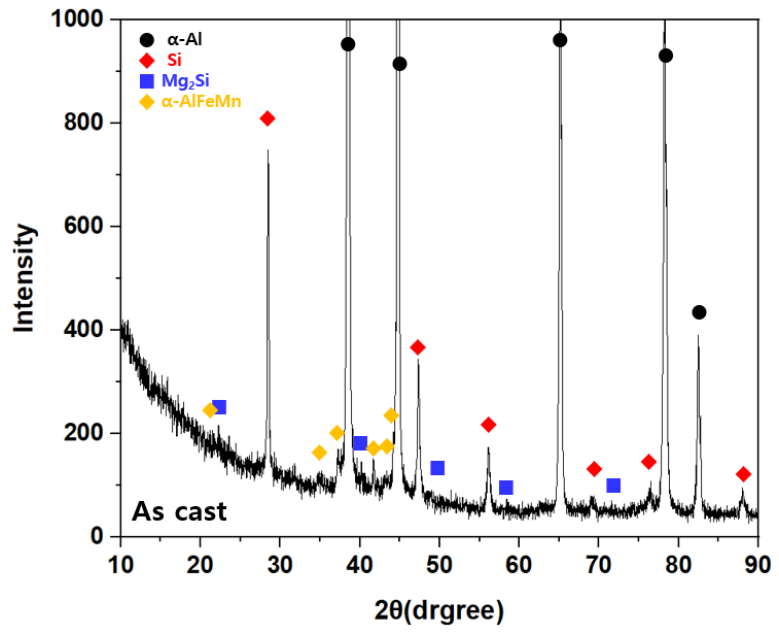

(a)

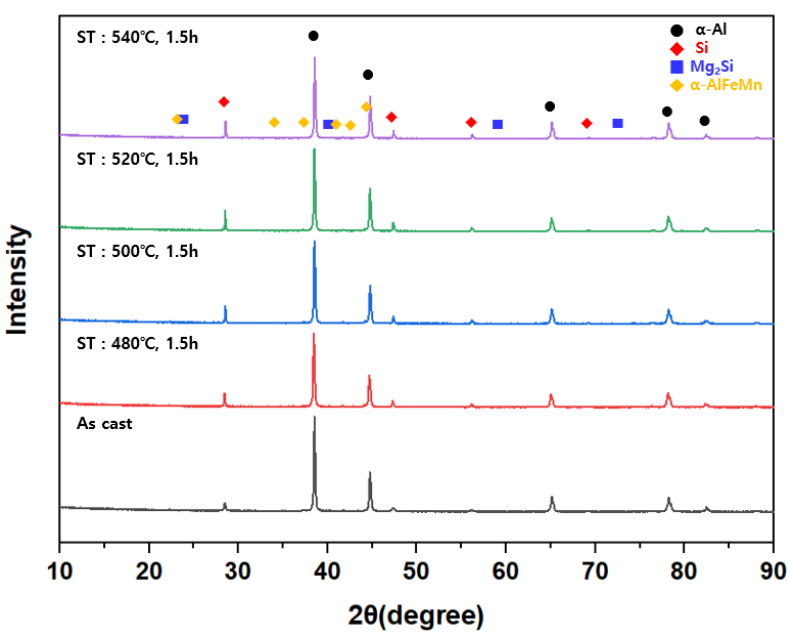

(b)

Figure 4. X-ray diffraction patterns of the as-cast and solution treated alloys: (a) X-ray diffraction patterns of as-cast $(\mathbf{b})$ comparison of the as-cast and each solution treated alloys.
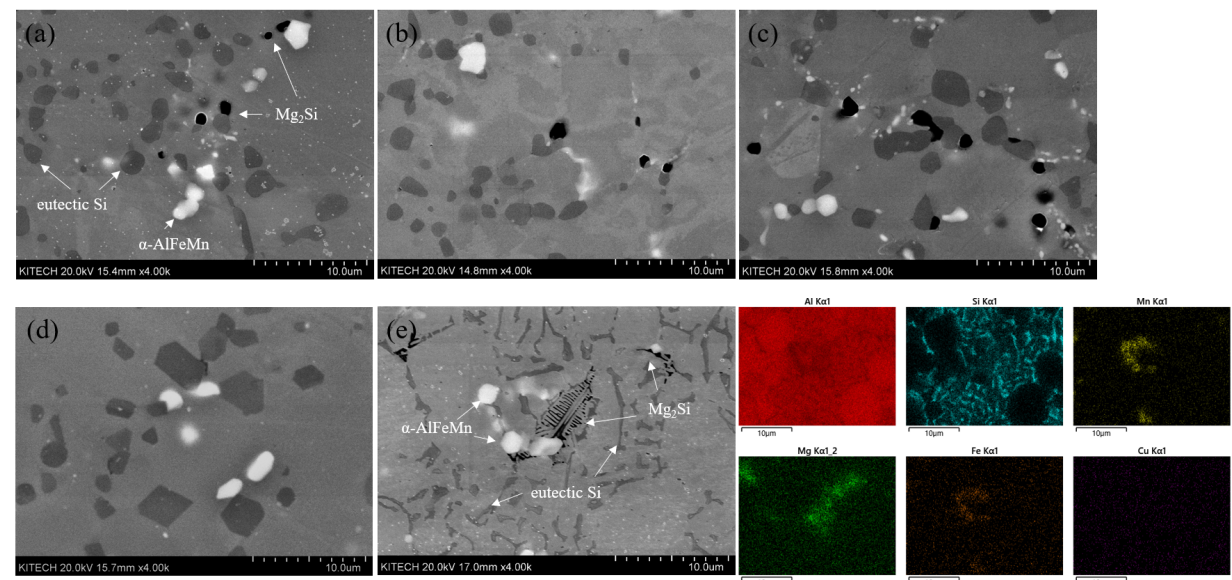

Figure 5. FE-SEM images of the cast alloy after the solution treatment for $90 \mathrm{~min}$ at (a) $480{ }^{\circ} \mathrm{C},(\mathbf{b}) 500{ }^{\circ} \mathrm{C}$, (c) $520^{\circ} \mathrm{C}$, and (d) $540{ }^{\circ} \mathrm{C}$ and (e) EDS images of the as-cast alloy. 
Table 3 shows the dendrite arm spacing (DAS), the volume fraction of the Si particles, and the porosity ratio values of the die-cast and solid solution heat-treated Al-11Si-0.5Mg alloys. The DAS of the solid solution heat-treated Al-11Si-0.5Mg alloys was larger than that of the die-cast Al-11Si-0.5Mg alloys. However, the difference among the DAS values of solid-solution heat-treated alloys at temperatures varying from 480 to $540{ }^{\circ} \mathrm{C}$ for $90 \mathrm{~min}$ was negligible. The difference among the Si particle volume fraction values of the diecast and the solid solution heat-treated alloys was also negligible. However, the solution temperature affected the average size and number of Si particles. The average size of the Si particles gradually increased with the increasing solution treatment temperature, whereas the number of Si particles significantly decreased. Shivkumar et al. [17] studied the variations in the size and number of Si particles during solution treatment. Due to the decreasing interfacial curvature and diffusion of Si particles, the relatively large particles are able to grow while smaller particles dissolve during spheroidization. This variation was prominent at $520^{\circ} \mathrm{C}$.

Table 3. Measurements of the dendrite arm spacing, volume fraction of the Si particles, and the porosity ratio after the solution treatment of the cast alloys.

\begin{tabular}{|c|c|c|c|c|c|c|c|c|c|c|c|}
\hline \multicolumn{2}{|c|}{$\begin{array}{l}\text { Solution } \\
\text { Treatment }\end{array}$} & \multicolumn{2}{|c|}{$\begin{array}{l}\text { DAS } \\
(\mu \mathrm{m})\end{array}$} & \multicolumn{2}{|c|}{$\begin{array}{l}\text { Si Particles Volume } \\
\text { Fraction }(\%)\end{array}$} & \multicolumn{2}{|c|}{$\begin{array}{c}\text { Si Particles Area } \\
\left(\mu \mathrm{m}^{2}\right)\end{array}$} & \multicolumn{2}{|c|}{ Aspect Ratio } & \multicolumn{2}{|c|}{ Casting Defect (\%) } \\
\hline $\begin{array}{l}\text { Temp. } \\
\left({ }^{\circ} \mathrm{C}\right)\end{array}$ & $\begin{array}{c}\text { Time } \\
\text { (h) }\end{array}$ & Average & SD & Average & SD & Average & SD & Average & SD & Average & SD \\
\hline- & - & 9.17 & 0.37 & 21.13 & 0.95 & 3.71 & 0.15 & 1.83 & 0.05 & 0.12 & 0.05 \\
\hline 480 & & 15.55 & 0.85 & 20.39 & 0.86 & 3.88 & 0.24 & 1.26 & 0.07 & 0.32 & 0.06 \\
\hline 500 & & 15.61 & 0.79 & 20.66 & 0.92 & 3.85 & 0.18 & 1.28 & 0.06 & 0.58 & 0.04 \\
\hline 520 & 1.5 & 15.31 & 0.77 & 20.12 & 0.96 & 4.59 & 0.21 & 1.26 & 0.05 & 1.12 & 0.10 \\
\hline 540 & & 15.20 & 0.89 & 21.07 & 0.99 & 4.89 & 0.27 & 1.24 & 0.10 & 3.53 & 0.16 \\
\hline
\end{tabular}

Figure 6 shows the growth of casting defects in the solution-treated and as-cast $\mathrm{Al}-\mathrm{Mg}$ Si alloys. The casting defect in the die-cast alloy occurs due to the presence of entrapped gases, which is attributed to the turbulent fluid during the filling of the sleeve [32]. These casting defects increased during heat treatment and negatively impact the mechanical properties $[9,18]$. Hu et al. [33] reported that the relationship between the pressure, temperature, and volume of gas porosity could be described according to Equation (1):

$$
\frac{p_{1} V_{1}}{T_{1}}=\frac{p_{2} V_{2}}{T_{2}}
$$

where $p$ is the pressure of the gas or air trapped in a porosity, $V$ is its volume, and $T$ is its temperature.
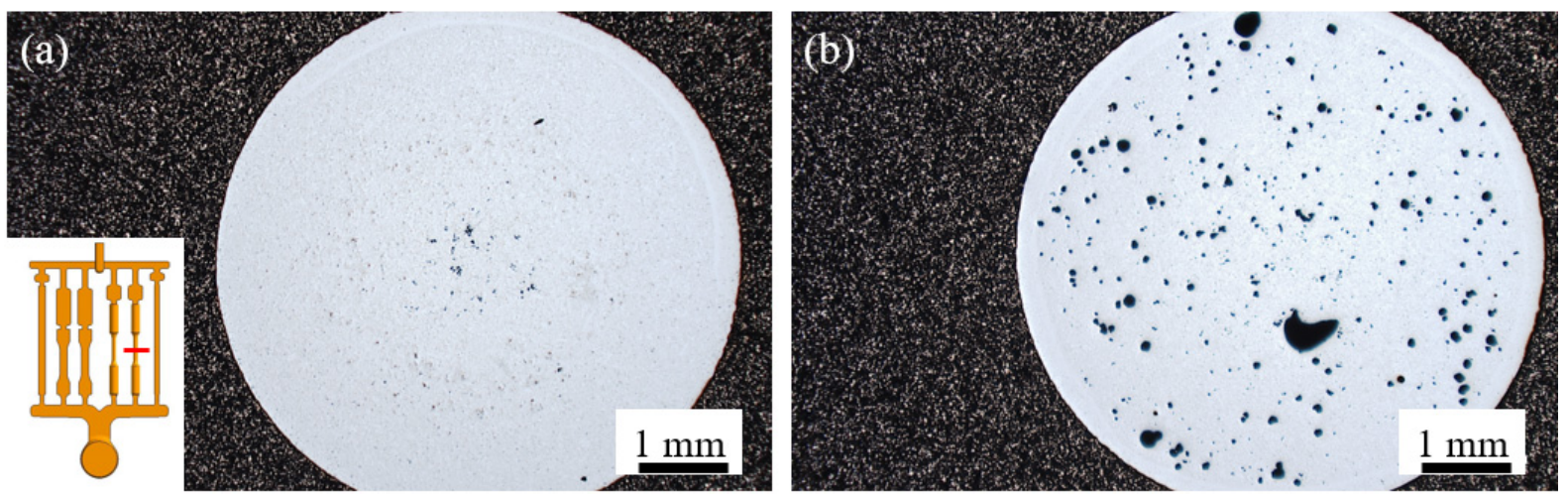

Figure 6. Optical micrographs of (a) the as-cast alloy and (b) the alloy after the solution treatment $540{ }^{\circ} \mathrm{C}$ for $90 \mathrm{~min}$. 
The increasing temperature during the solution treatment decreases the strength of the specimens and increases the pressure of the gas porosity. The gas porosity expands and eventually blisters when the pressure of the gas porosity exceeds the strength of the specimen. As a result, the number of casting defects increases with the rising solution temperature. It is important to control and minimize the casting defects during heat treatment. Therefore, it is necessary to analyze the effects of the casting defects, which increase with an increase in the solid solution temperature, on the mechanical properties of these alloys, as shown in Table 3.

Figure 7 and Table 4 show the variation in the aspect ratios of the Si particles with the solution temperature. A rise in the solution temperature at a constant heat treatment duration increased the fraction of the adjacent aspect ratio value at 1.0. This implies that the needle-type eutectic Si particle transformed into spherical particles.

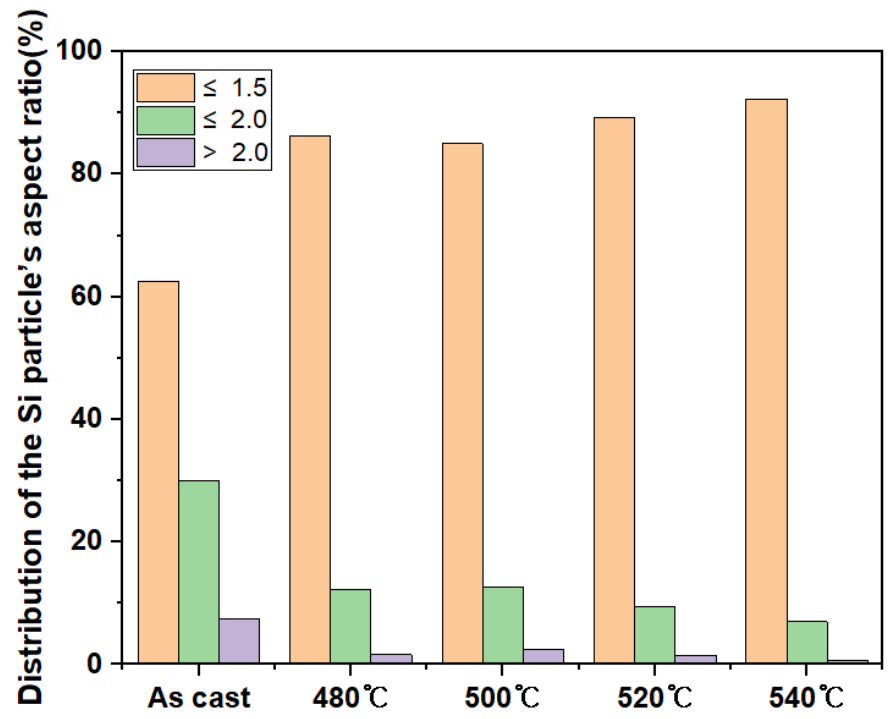

Figure 7. Distribution of the aspect ratios of the Si particles.

Table 4. Measurements of the Si particles' aspect ratios.

\begin{tabular}{cccccc}
\hline \multicolumn{2}{c}{ Solid Solution Heat Treatment } & \multicolumn{5}{c}{ Aspect Ratio (\%) } \\
\hline Temperature $\left({ }^{\circ} \mathbf{C}\right)$ & Time (Min) & $\leq \mathbf{1 . 5 0}$ & $\leq \mathbf{2 . 0 0}$ & $>\mathbf{2 . 0}$ & Total \\
\hline- & - & 62.5 & 30.0 & 7.5 & 100 \\
480 & & 86.3 & 12.2 & 1.6 & 100 \\
500 & \multirow{2}{*}{$1.5 \mathrm{~h}$} & 85.0 & 12.6 & 2.4 & 100 \\
520 & & 89.2 & 9.4 & 1.5 & 100 \\
540 & & 92.3 & 7.0 & 0.7 & 100 \\
\hline
\end{tabular}

The stress-strain curves of the as-cast and solution heat-treated Al-Mg-Si alloys are shown in Figure 8 and the calculated values are listed in Table 5. The yield strength (YS), ultimate tensile strength (UTS), and elongation (EL) of the as-cast Al-Si-Mg alloy were 155.32 MPa, 290.99 MPa, and 5.17\%, respectively. The YS and UTS of the solution-treated Al-Si-Mg alloys decreased, while their EL increased significantly. A rise in the solution heat treatment temperature from 480 to $520^{\circ} \mathrm{C}$ increased the YS and UTS by more than 23 and $21 \mathrm{MPa}$, respectively. The EL of the solution-treated alloys were slightly reduced. The heat treatment at $540{ }^{\circ} \mathrm{C}$ for $90 \mathrm{~min}$ decreased the UTS and EL values by 10 and $20 \mathrm{MPa}$, respectively, and increased the YS by $9.1 \%$. These trends were attributed to the variation in the DAS, the precipitate behaviour of the Si particles, and the casting defects. The mechanical properties of the cast Al alloys depend heavily on the variation in the DAS, which is responsible for the differences between the mechanical properties of the cast and 
solution-treated Al-Mg-Si alloys [34]. Furthermore, the refined Si particles formed by die casting can improve the YP and UTS $[9,18,20,30]$.

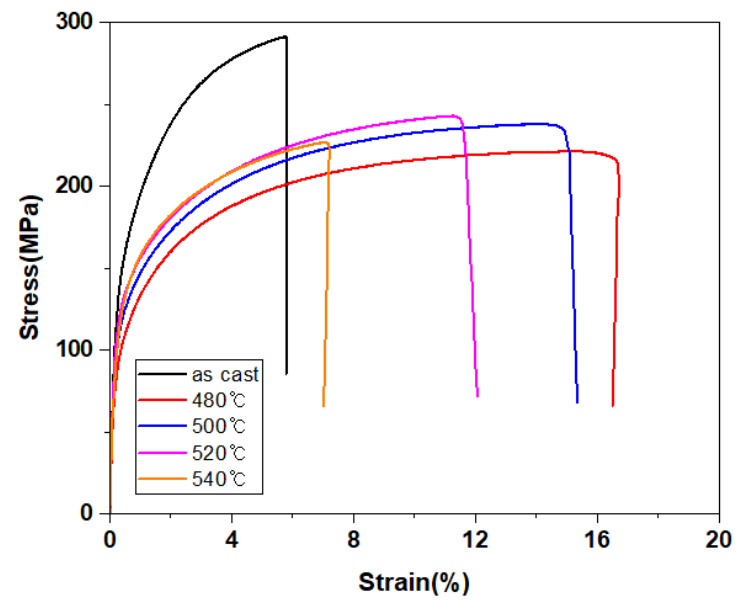

Figure 8. Stress-strain curves of the as-cast and solution-treated alloys.

Table 5. Tensile properties of as-cast and solution-treated alloys.

\begin{tabular}{|c|c|c|c|c|c|c|c|}
\hline \multicolumn{2}{|c|}{ Solution Treatment } & \multicolumn{2}{|c|}{$\begin{array}{c}\text { YS } \\
(\mathrm{MPa})\end{array}$} & \multicolumn{2}{|c|}{$\begin{array}{l}\text { UTS } \\
\text { (MPa) }\end{array}$} & \multicolumn{2}{|c|}{$\begin{array}{l}\text { EL } \\
(\%)\end{array}$} \\
\hline Temp. $\left({ }^{\circ} \mathrm{C}\right)$ & Time (Min) & Average & SD & Average & SD & Average & SD \\
\hline- & - & 155.32 & 4.15 & 290.99 & 10.24 & 5.17 & 0.64 \\
\hline 480 & & 102.96 & 8.89 & 224.25 & 14.15 & 13.93 & 1.50 \\
\hline 500 & & 116.25 & 9.15 & 237.57 & 14.25 & 13.76 & 1.67 \\
\hline 520 & 90 & 126.06 & 8.95 & 245.90 & 15.26 & 12.64 & 1.65 \\
\hline 540 & & 129.58 & 9.51 & 214.20 & 16.58 & 4.84 & 1.65 \\
\hline
\end{tabular}

Although the growth of the Si particles after the solution heat treatment reduced the YS and UTS, the transformed morphology of the Si particles can considerably improve the elongation of the alloy. Lin et al. [20] reported that the size and density of the Si particles are able to gradually increase by different proportions for different solution treatment durations, which vary from 1 to $8 \mathrm{~h}$. However, the heterogenous distribution of Si particles and the formation of Si-containing dispersoid-free zones can cause dispersion hardening; a similar effect has also been reported by Lin et al. [25]. The dispersoids were partially coherent with the $\alpha-\mathrm{Al}$ matrix, which resulted in the formation of an elastic coherent strain field. Thus, the dispersoids play an important role in increasing the microhardness. The rise in the YS and UTS values with the increasing solution heat-treat temperature can be explained by the changes in the morphologies of the Si particles and the coherence between the $\mathrm{Al}$ matrix and Si particles. However, a rise in the solution heat-treat temperature of up to $540{ }^{\circ} \mathrm{C}$ led to a significant reduction in the YS and UTS due to the increasing casting defects.

The stress-strain curves of the $\mathrm{Al}-\mathrm{Si}-\mathrm{Mg}$ alloys after the solid solution heat treatment at $520{ }^{\circ} \mathrm{C}$ for $90 \mathrm{~min}$, followed by an aging heat treatment, are shown in Figure 9 and the calculated values are listed in Table 6 . The YS and UTS values increased, while the EL decreased in comparison to those of the solution heat-treated only Al-Mg-Si alloys. Moreover, the YS, UTS, and EL values were significantly superior to those obtained from the tensile tests of the as-cast Al-Mg-Si alloys. The maximum YS and UTS values were obtained after subjecting the alloy to aging heat treatment at $180^{\circ} \mathrm{C}$ for $180 \mathrm{~min}$. These treatment conditions ensured that the aging temperature was maximum among the trials conducted for a fixed heat treatment duration. However, the value of EL decreased slightly. The rise in the YS values of the aging heat-treated $\mathrm{Al}-\mathrm{Mg}-\mathrm{Si}$ alloys became prominent with a higher aging temperature. The maximum strength of the aging heat-treated $\mathrm{Al}$ alloy was 
obtained just before the incoherent precipitation of the $\mathrm{Al}$ matrix, resulting in relatively less elongation [35]. Therefore, the optimum heat treatment conditions for controlling the Si particles and casting defects were obtained by an appropriate combination of the solid solution and aging heat treatments.

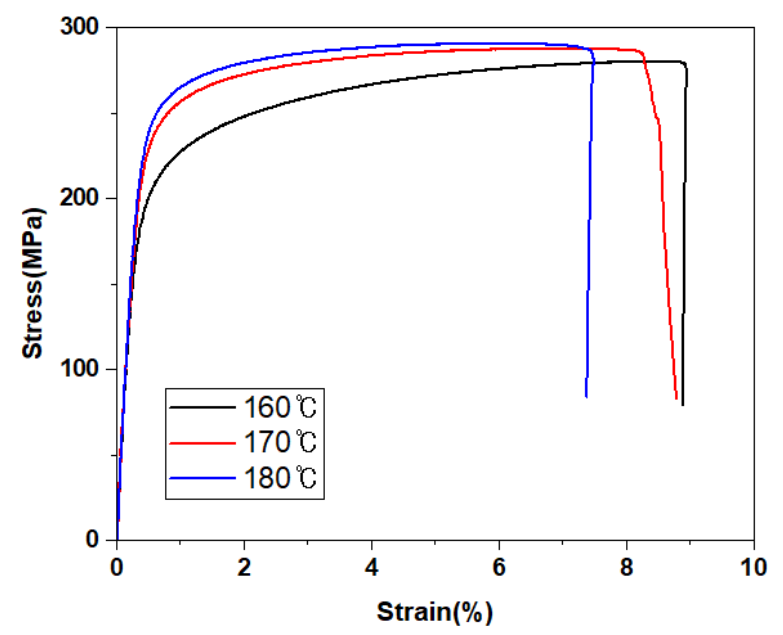

Figure 9. Stress-strain curves of the alloys after the solid solution heat treatment at $520^{\circ} \mathrm{C}$ for $90 \mathrm{~min}$, followed by aging heat treatment for $180 \mathrm{~min}$ at $\mathrm{a}-160^{\circ} \mathrm{C}, \mathrm{b}-170^{\circ} \mathrm{C}$, and $\mathrm{c}-180^{\circ} \mathrm{C}$.

Table 6. Tensile properties of the alloy after the solid solution heat treatment and aging heat treatment.

\begin{tabular}{|c|c|c|c|c|c|c|}
\hline \multicolumn{2}{|c|}{ Solution Treatment } & \multicolumn{2}{|c|}{ Age Treatment } & \multirow{2}{*}{$\begin{array}{c}\text { YS } \\
(\mathrm{MPa})\end{array}$} & \multirow{2}{*}{$\begin{array}{c}\text { UTS } \\
\text { (MPa) }\end{array}$} & \multirow{2}{*}{$\begin{array}{l}\text { EL } \\
(\%)\end{array}$} \\
\hline $\begin{array}{c}\text { Temp. } \\
\left({ }^{\circ} \mathrm{C}\right)\end{array}$ & $\begin{array}{l}\text { Time } \\
\text { (Min) }\end{array}$ & $\begin{array}{c}\text { Temp. } \\
\left({ }^{\circ} \mathrm{C}\right)\end{array}$ & $\begin{array}{l}\text { Time } \\
\text { (Min) }\end{array}$ & & & \\
\hline \multirow{3}{*}{520} & \multirow{3}{*}{90} & 160 & \multirow{3}{*}{180} & 196.81 & 280.51 & 8.94 \\
\hline & & 170 & & 224.78 & 287.98 & 8.43 \\
\hline & & 180 & & 239.50 & 290.50 & 7.49 \\
\hline
\end{tabular}

\section{Conclusions}

This study analyzed the impact of solution and artificial aging treatments on the microstructure of an as-cast $\mathrm{Al}-\mathrm{Mg}-\mathrm{Si}$ alloy fabricated by high-pressure die casting. It was composed of $\alpha-\mathrm{Al}$, complex needle-type eutectic Si particles, $\mathrm{Mg}_{2} \mathrm{Si}$, and $\alpha$-AlFeMn. The solution treatment broke down the complex needle-type eutectic $\mathrm{Si}$ particles into a spheroidal morphology and dissolved the $\mathrm{Mg}_{2} \mathrm{Si}$. The increasing solution treatment temperature gradually increased the number of casting defects in the as-cast $\mathrm{Al}-\mathrm{Mg}-\mathrm{Si}$ alloy.

The maximum YS and UTS values were obtained when the alloy was solution heattreated at $520{ }^{\circ} \mathrm{C}$ for $90 \mathrm{~min}$. Although the YS and UTS values of the Al-Mg-Si alloys decreased due to the solution treatment, the EL of the solution-treated $\mathrm{Al}-\mathrm{Mg}-\mathrm{Si}$ alloys was greater than that of the as-cast Al-Mg-Si alloy. The highest YS and UTS values were obtained after aging heat treatment at $180{ }^{\circ} \mathrm{C}$ for $180 \mathrm{~min}$. However, the EL of the aging heat-treated alloy decreased slightly.

Author Contributions: H.-J.K., J.-Y.P. and D.-H.C. conceived and designed the experiments; H.-J.K. performed the experiments; H.-J.K., D.-H.C., J.-Y.P. and Y.-S.C. analyzed and discussed the data. H.-J.K., D.-H.C. and Y.-S.C. wrote the paper. All authors have read and agreed to the published version of the manuscript.

Funding: This work was supported by the Ministry of Economy and Finance (code no. SE210002), Korea.

Data Availability Statement: The data presented in this study are available on request from the corresponding author. The data are not publicly available due to an ongoing study.

Conflicts of Interest: The authors have no conflict of interest. 


\section{References}

1. Zhang, D.L.; Zheng, L.H.; StJohn, D.H. Effect of Solution Treatment Temperature on Tensile Properties of AI-7Si-O.3Mg (wt-\%) Alloy. Mater. Sci. Technol. 1998, 14, 619-625. [CrossRef]

2. Beroual, S.; Boumerzoug, Z.; Paillard, P.; Borjon-Piron, Y. Effects of Heat Treatment and Addition of Small Amounts of Cu and $\mathrm{Mg}$ on the Microstructure and Mechanical Properties of Al-Si-Cu and Al-Si-Mg Cast Alloys. J. Alloys Compd. 2019, 784, 1026-1035. [CrossRef]

3. Caceres, C.H.; Davidson, C.J.; Griffiths, J.R.; Wang, Q.G. The Effect of Mg on the Microstructure and Mechanical Behavior of Al-Si-Mg Casting Alloys. Metall. Mater. Trans. A 1999, 30, 2611-2618. [CrossRef]

4. Xu, C.; Wang, F.; Mudassar, H.; Wang, C.; Hanada, S.; Xiao, W.; Ma, C. Effect of Sc and Sr on the Eutectic Si Morphology and Tensile Properties of Al-Si-Mg Alloy. J. Mater. Eng. Perform. 2017, 26, 1605-1613. [CrossRef]

5. Solórzano, G. Solidification and Precipitation Behaviour of Al-Si-Mg Casting Alloys. J. Mater. Sci. 2001, 36, 739-750. [CrossRef]

6. Wang, Y.; Liao, H.; Wu, Y.; Yang, J. Effect of Si Content on Microstructure and Mechanical Properties of Al-Si-Mg Alloys. Mater. Des. 2014, 53, 634-638. [CrossRef]

7. Vončina, M.; Medved, J.; Kores, S.; Xie, P.; Schumacher, P.; Li, J. Precipitation Microstructure in Al-Si-Mg-Mn Alloy with Zr Additions. Mater. Charact. 2019, 155, 2-9. [CrossRef]

8. Jang, H.S.; Kang, H.J.; Park, J.Y.; Choi, Y.S.; Shin, S. Effects of Casting Conditions for Reduced Pressure Test on Melt Quality of Al-Si Alloy. Metals 2020, 10, 1422. [CrossRef]

9. Ye, H. An Overview of the Development of Al-Si-Alloy Based Material for Engine Applications. J. Mater. Eng. Perform. 2003, 12, 288-297. [CrossRef]

10. Hartlieb, M. Aluminum Alloys for Structural Die Casting. Die Cast. Eng. 2013, 57, 40-43.

11. Brito, C.; Costa, T.A.; Vida, T.A.; Bertelli, F.; Cheung, N.; Spinelli, J.E.; Garcia, A. Characterization of Dendritic Microstructure, Intermetallic Phases, and Hardness of Directionally Solidified Al-Mg and Al-Mg-Si Alloys. Metall. Mater. Trans. A 2015, 46, 3342-3355. [CrossRef]

12. Yang, W.; Yang, X.; Ji, S. Melt Superheating on the Microstructure and Mechanical Properties of Diecast Al-Mg-Si-Mn Alloy. Met. Mater. Int. 2015, 21, 382-390. [CrossRef]

13. Cai, Q.; Mendis, C.L.; Chang, I.T.H.; Fan, Z. Microstructure Evolution and Mechanical Properties of New Die-Cast Al-Si-Mg-Mn Alloys. Mater. Des. 2020, 187, 108394. [CrossRef]

14. Kim, K.-J.; Kim, H.-J.; Jeong, C.-Y. Mechanical and die soldering properties of Al-Si-Mg-Mn cast alloy. Mater. Res. Innov. 2014, 18, S2666-S2672. [CrossRef]

15. Kohlhepp, M.; Uggowitzer, P.J.; Hummel, M.; Höppel, H.W. Formation of die soldering and the influence of alloying elements on the intermetallic interface. Materials 2021, 14, 1580. [CrossRef] [PubMed]

16. Paray, F.; Gruzleski, J.E. Modification-a Parameter to Consider in the Heat Treatment of Al-Si Alloys. Cast Met. 1992, 5, 187-198. [CrossRef]

17. Shivkumar, S.; Ricci, S.; Keller, C.; Apelian, D. Effect of Solution Treatment Parameters on Tensile Properties of Cast Aluminum Alloys. J. Heat Treat. 1990, 8, 63-70. [CrossRef]

18. Yan, F.; Yang, W.; Ji, S.; Fan, Z. Effect of Solutionising and Ageing on the Microstructure and Mechanical Properties of a High Strength Die-Cast Al-Mg-Zn-Si Alloy. Mater. Chem. Phys. 2015, 167, 88-96. [CrossRef]

19. Moustafa, M.A.; Samuel, F.H.; Doty, H.W. Effect of Solution Heat Treatment and Additives on the Microstructure of Al-Si (A413.1) Automotive Alloys. J. Mater. Sci. 2003, 8, 4507-4522. [CrossRef]

20. Lin, Y.; Luo, S.-C.; Huang, J.; Yin, L.-X.; Jiang, X.-Y. Effects of Solution Treatment on Microstructures and Micro-Hardness of a Sr-Modified Al-Si-Mg Alloy. Mater. Sci. Eng. A 2018, 725, 530-540. [CrossRef]

21. Daswa, P.; Moller, H.; Govender, G. Overageing Characteristics of Alloy a356 and Al-Mg-Si Casting Alloys. Solid State Phenom. 2019, 285, 75-80. [CrossRef]

22. Ibrahim, M.F.; Samuel, A.M.; Doty, H.W.; Samuel, F.H. Effect of Aging Conditions on Precipitation Hardening in Al-Si-Mg and Al-Si-Cu-Mg Alloys. Int. J. Meteorol. 2017, 11, 274-286. [CrossRef]

23. Li, R.X.; Li, R.D.; Zhao, Y.H.; He, L.Z.; Li, C.X.; Guan, H.R.; Hu, Z.Q. Age-Hardening Behavior of Cast Al-Si Base Alloy. Mater. Lett. 2004, 58, 2096-2101. [CrossRef]

24. Sharma, R.; Anesh, D.; Dwivedi, D.K. Influence of Silicon (wt.\%) and Heat Treatment on Abrasive Wear Behaviour of Cast Al-Si-Mg Alloys. Mater. Sci. Eng. A 2005, 408, 274-280. [CrossRef]

25. Lin, Y.; Luo, S.-C.; Yin, L.-X.; Huang, J. Microstructural Evolution and High Temperature Flow Behaviors of a Homogenized Sr-Modified Al-Si-Mg Alloy. J. Alloys Compd. 2018, 739, 590-599. [CrossRef]

26. Zhang, D.L.; Zheng, L.H.; StJohn, D.H. Effect of a Short Solution Treatment Time on Microstructure and Mechanical Properties of modified Al-7wt.\% Si-0.3 wt.\% Mg alloy. J. Light Met. 2002, 2, 27-36. [CrossRef]

27. Long, H.C.; Chen, J.H.; Liu, C.H.; Li, D.Z.; Li, Y.Y. The Negative Effect of Solution Treatment on the Age Hardening of A356 Alloy. Mater. Sci. Eng. A 2013, 566, 112-118. [CrossRef]

28. Kang, H.-J.; Jang, H.-S.; Oh, S.-H.; Yoon, P.-H.; Lee, G.-H.; Park, J.-Y.; Kim, E.-S.; Choi, Y.-S. Effects of solution treatment temperature and time on the porosities and mechanical properties of vacuum die-casted and T6 heat-treated Al-Si-Mg alloy. Vacuum 2021, 193, 110536. [CrossRef] 
29. Kang, H.J.; Yoon, P.H.; Lee, G.H.; Park, J.Y.; Jung, B.J.; Lee, J.Y.; Lee, C.U.; Kim, E.S.; Choi, Y.S. Evaluation of the Gas Porosity and Mechanical Properties of Vacuum Assisted Pore-Free Die-Cast Al-Si-Cu Alloy. Vacuum 2021, 184, 109917. [CrossRef]

30. Li, J.H.; Barrirero, J.; Engstler, M.; Aboulfadl, H.; Mücklich, F.; Schumacher, P. Nucleation and Growth of Eutectic Si in Al-Si Alloys with Na Addition. Metall. Mater. Trans. A 2015, 46, 1300-1311. [CrossRef]

31. Wang, J.; Guo, Z.; Song, J.L.; Hu, W.X.; Li, J.C.; Xiong, S.M. Morphology Transition of the Primary Silicon Particles in a Hypereutectic A390 Alloy in High Pressure die Casting. Sci. Rep. 2017, 7, 14994. [CrossRef]

32. Toda, H.; Qu, P.C.; Ito, S.; Shimizu, K.; Uesugi, K.; Takeuchi, A.; Suzuki, Y.; Kobayashi, M. Formation Behaviour of Blister in Cast Aluminium Alloy. Int. J. Cast Met. Res. 2014, 27, 369-377. [CrossRef]

33. Battaglia, E.; Bonollo, F.; Ferro, P.; Fabrizi, A. Effect of Heat Treatment on Commercial AlSi12Cu1(Fe) and AlSi12(b) Aluminum Alloy Die Castings. Metall. Mater. Trans. A 2018, 49, 1631-1640. [CrossRef]

34. Birol, Y. Impact of Grain Size on Mechanical Properties of AlSi7Mg0.3 Alloy. Mater. Sci. Eng. A 2013, 559, 394-400. [CrossRef]

35. Chen, R.; Xu, Q.; Guo, H.; Xia, Z.; Wu, Q.; Liu, B. Correlation of Solidification Microstructure Refining Scale, Mg Composition and Heat Treatment Conditions with Mechanical Properties in Al-7Si-Mg Cast Aluminum Alloys. Mater. Sci. Eng. A 2017, 685, 391-402. [CrossRef] 